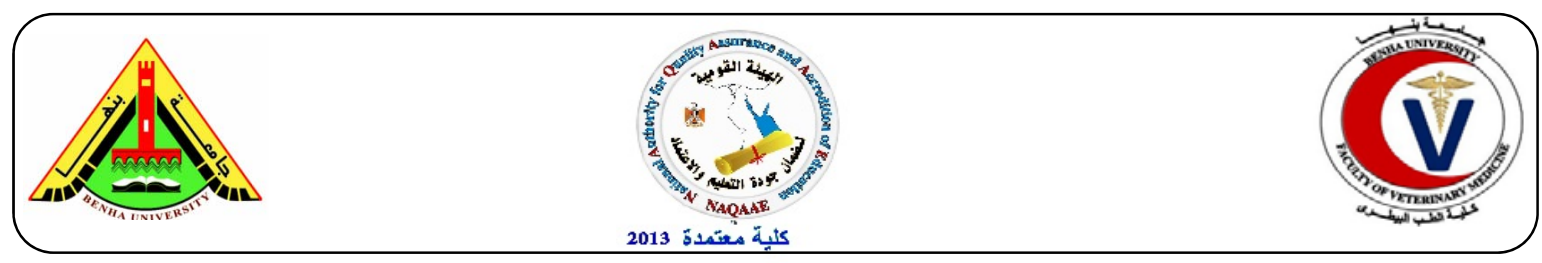

\title{
Molecular characterization for some virulence and antibiotic resistance genes of Staphylococcus aureus isolated from dairy cattle's subclinical mastitis in EL- Sharkia Governorate.
}

\author{
Ashraf, A. Abd El-Tawab ${ }^{1}$, Ahmad, M. Amaar ${ }^{2}$, Mokhtar, Abd El-Hakeem Sleim ${ }^{3}$, Fatma, I. El \\ Hofy ${ }^{1}$, Heba, S. S. Salem ${ }^{3}$. \\ ${ }^{1}$ Bacteriology, Immunology and Mycology Dep., Fac. of Vet. Med., Benha Univ., ${ }^{2}$ Bacteriology, \\ Immunology and Mycology Dep., Fac. of Vet. Med., Zagazig Univ., ${ }^{3}$ Animal Health Research Institute \\ (Zagazig branch).
}

\begin{abstract}
A B S T R A C T
Staphylococcus aureus has emerged as a significant public health problem as it is often responsible for intramammary infection in bovine. The emergence of MRSA in animals was from an outbreak of mastitis in cattle which represent a great economic in milk industry. The present study was carried out to genotypically characterized S. aureus isolated from subclinical bovine mastitis in different farms in EL- Sharkia Governorate. A total of 15 S. aureus isolates were obtained from 100 subclinical mastitic milk samples and subjected to PCR for detection of some virulence and antimicrobial resistance genes using oligonucleotide primers that amplified genes encoding enterotoxin genes A to E (sea, seb, sec, sed, see), coagulase gene (coa), the IgG binding region of protein A (spa) and resistance gene as factor essential for expression of methicillin resistance ( femA) which was used as an internal positive control and intrinsic methicillin resistance gene (mecA). PCR amplification revealed that all S. aureus isolates were enterotoxogenic and MRSA, harbored the genes encoding staphylococcal coagulase and the genes encoding the immunoglobulin $\mathrm{G}$ binding region of protein $\mathrm{A}$. The data in the study provided an overview on the distribution of virulence determinants of MRSA strains which contributed to bovine mastitis problem in the Egypt farm.
\end{abstract}

Keywords: Staphylococcus aureus, Polymorphism, Genotyping, Virulence factors, Mastitis.

(http://www.bvmj.bu.edu.eg) (BVMJ-30(1): 219-230, 2016)

\section{INTRODUCTION}

S taphylococcus aureus is an opportunistic pathogen in dairy ruminant where it is found in healthy carriage and can be a major cause of mastitis (Seyffert et al., 2012). S.aureus is recognized worldwide as a frequent cause of subclinical intramammary infections in dairy cows. The main reservoir of $S$. aureus seems to be the infected quarter and transmission between cows usually occurs during milking $S$. aureus produces a spectrum of extra cellular protein toxins and virulence factors which are thought to contribute to the pathogenicity of the organism (Momtaz et al., 2010). A variety of virulence factors that is responsible for subclinical and persistent intramammary infections (Fitzgerald et al., 2000). Staphylococcal enterotoxins (SEs) are serologically grouped into five major classical types. However, other new enterotoxins have been described (Thomas et al., 2007). Sea and seb are usually more common in milk and milk products (Chiang et al., 2006). Several studies reported the production of SEs or the presence of toxin genes in Staphylococcus aureus from milk and derivate associated with mastitis cows in different countries (Normanno et al., 2005). Additionally, coagulase has also 
been shown to be a virulence factor in intrammmary infection. This protein is coded by coa gene that possesses a conserved and a repeated polymorphic region that can be used to measure relatedness among $S$. aureus isolates (Reinoso, 2004). Coagulase protein has the ability to turn fibrinogen into fibrin threads by a mechanism different from natural clotting (Palma et al., 1999). Staphylococcus aureus encodes many virulence factors including the surface IgGbinding protein $\mathrm{A}$ ( $\mathrm{spa}$ ) whose function is to capture the $\mathrm{Fc}$ region of immunoglobulin of most mammalian species therefore prevent phagocytosis of the bacterial cells by the host immune system (Foster, 2005). Besides virulence factors, the increased resistance of $S$. aureus isolated from mastitic cows to several antimicrobial agents has been reported (Gentilini et al., 2000), what impacts the effectiveness of therapy since control methods of this organism from dairy herds requires treatment of infected mammary glands with effective antimicrobial agents (Kirkanet al., 2005). MRSA detection has been reported in milk from mastitic cows (Goniet al., 2004). The most commonly known carrier of the mecA gene is the bacterium known as MRSA. MecA, a structural gene located on the chromosome of $S$. aureus, characterizes methicillin resistant $S$. aureus (MRSA) and femA gene encode proteins which influence the level of methicillin resistance of $S$. aureus (Kobayash et al.,1994). The outcome of this work is molecular detection of virulence genes of $S$. aureus involving in subclinical mastitic cases beside the acquition of methicillin resistance as little information is available about virulence determinant of these bacteria in Egypt.

\section{MATERIAL AND METHODS}

\subsection{Bacterial Isolates and culture media}

Milk samples were collected aseptically from 475 cows with subclinical mastitis in EL-Sharkia Governorate. Milk samples from apparently healthy animals were tested for subclinical mastitis by CMT and SCC (Radostits et al., 1994) and (Kot et al., 2012), respectively. Milk samples for CMT positive animals (considered as SCM positive) were induced in the present study for detection of $S$. aureus. A total of coagulase positive Staphylococcus isolates was included in this investigation. Milk samples were inoculated onto blood agar base (Merck) supplemented with 5\% defibrinated sheep blood. Isolates were identified by conventional methods, including Gram staining, colony morphology, haemolysis tests for catalase, coagulase and anaerobic fermentation of mannitol (Konemanet al., 2001). All strains were stored on suitable maintenance media in the National Laboratory for Bacteriology, Laboratory center for PCR. Bacterial cultures were grown in brain heart infusion broth prior to extraction of total DNA.

\subsection{PCR amplification}

PCR amplification was performed with PTC-100 programmable thermal cycler (Peltier Effect cycling, MJ, Research, INC, $\mathrm{UK}$ ) in a volume of $50 \mathrm{ml}$ consisting of: 12.5 $\mu \mathrm{l}$ of Emerald Amp GT PCR master mix (2x premix), $1 \mu \mathrm{l}$ of $20 \mathrm{pmol}$ of each primer for one sample, $6 \mu \mathrm{l}$ of the DNA template and water, nuclease-free up to 25 $\mu \mathrm{l}$ in uniplex PCR. While, $25 \mu \mathrm{l}$ of Emerald Amp GT PCR master mix (2x premix), $1 \mu \mathrm{l}$ of $20 \mathrm{pmol}$ of each primer for one sample, $10 \mu 1$ of the DNA template and water, nuclease-free up to $50 \mu \mathrm{l}$ in PCR.

Primer sequence and PCR amplification cycles of oligonucleotide primers among the selected isolates are illustrated in Tables (1 and 2).

\section{RESULTS}

One hundred (21\%) samples from 475 cows were found to be CMT positive. On the basis of cultural and biochemical properties, 61 isolates were identified as $S$. aureus. All 61 isolates were positive for the catalase test, the tube coagulase test, 
hemolysis on blood agar and gave golden pigment on milk agar. The results of PCR for $15 \mathrm{~S}$. aureus isolates revealed that all 15 isolates of $S$. aureus were enterotoxigenic, positive for coagulase gene with polymorphism and spa gene. The amplification of the coa gene displayed three different size polymorphisms with about 430bp, 630bp and 750bp as shown in fig. (1). Spa gene represented IgG binding region of protein A with revealing size of 226 bp (Fig. 2). Additionally, all examined isolates was enterotoxiginic with predominance for see in uniplex. Thirteen $(86.7 \%)$ isolates were positive for enterotoxin A gene, $6(40 \%)$ isolates harboured enterotoxin $B$ gene and enterotoxin $\mathrm{C}$ gene. Inionically, sed was not detected in any $S$. aureus isolates as shown in fig. (5, 6, 7, 8 and 9). All 15 isolates were positive for femA and mecA genes yielding an amplicon size of $132 \mathrm{bp}$ and $310 \mathrm{bp}$, respectively (Fig. 3 and 4). The results of multiplex PCR for $15 \mathrm{~S}$. aureus showed that the predominant enterotoxigenic gene was see gene followed sea and seb among $S$. aureus isolates. Additionally, it was also found in combination with sea and seb genes as shown in fig. (10).

Table (1): Oligonucleotide primers sequences of all primers used in PCR amplification assays and their respective PCR product size

\begin{tabular}{llll}
\hline Gene & Primer & $\begin{array}{l}\text { Primer sequence } \\
\left(5^{\prime}-3^{\prime}\right)\end{array}$ & Length of amplified product \\
\hline sea & SEA-F & GGTTATCAATGTGCGGGTGG & $102 \mathrm{bp}$ \\
& SEA-R & CGGCACTTTTTCTCTTCGG & \\
seb & SEB-F & GTATGGTGGTGTAACTGAGC & $164 \mathrm{bp}$ \\
& SEB-R & CCAAATAGTGACGAGTTAGG & \\
sec & SEC-F & AGATGAAGTAGTTGATGTGTATGG & $451 \mathrm{bp}$ \\
& SEC-R & CACACTTTTAGAATCAACCG & \\
sed & SED-F & CCAATAATAGGAGAAAATAAAAG & $278 \mathrm{bp}$ \\
& SED-R & ATTGGTATTTTTTTCGTTC & \\
see & SEE-F & AGGTTTTTTCACAGGTCATCC & $209 \mathrm{bp}$ \\
& SEE-R & CTTTTTTCTTCGGTCAATC & \\
mec & mecA-1 & GTAGAAATGACTGAACGTCCGATAA & $310 \mathrm{bp}$ \\
A & mecA-2 & CCAATTCCACATTGTTTCGGTCTAA & \\
coa & Coa-F & ATAGAGATGCTGGTACAGG & Four different types of bands may \\
& Coa-R & GCTTCCGATTGTTCGATGC & be detected \\
& & & $350 \mathrm{bp}$ \\
& & & $430 \mathrm{bp}$ \\
& & & $570 \mathrm{bp}$ \\
& & & $630 \mathrm{bp}$ \\
spa & Spa-F5 & TCA ACA AAG AAC AAC AAA ATG C & $226 \mathrm{bp}$ \\
& Spa-R8 & GCT TTC GGT GCT TGA GAT TC & \\
femA & FEMA-F & AAAAAAGCACATAACAAGCG & $132 \mathrm{bp}$ \\
& FEMA-R & GATAAAGAAGAAACCAGCAG & \\
\hline
\end{tabular}


Table (2): Cycling conditions for amplification of some virulence and resistant genes, among S. aureus isolates.

\begin{tabular}{|c|c|c|c|c|}
\hline Target gene & $\begin{array}{c}\text { Initial } \\
\text { denaturation }\end{array}$ & Actual cycles & $\begin{array}{c}\text { Final } \\
\text { extension }\end{array}$ & Reference \\
\hline \multirow{2}{*}{$\begin{array}{c}\text { sea, seb and } \\
\text { see }\end{array}$} & $94^{\circ} \mathrm{C}$ & 35 cycles of : & $72^{\circ} \mathrm{C}$ & \multirow{6}{*}{$\begin{array}{c}\text { Mehrotra et al., } \\
2000\end{array}$} \\
\hline & $5 \mathrm{~min}$. & $\begin{array}{l}\text { Denaturation: } 94^{\circ} \mathrm{C} / 30 \mathrm{sec} \text {. } \\
\text { Annealing: } 50 / 30 \mathrm{sec} \text {. } \\
\text { Extension: } 72 / 30 \mathrm{sec} \text {. }\end{array}$ & $7 \mathrm{~min}$. & \\
\hline \multirow[t]{2}{*}{ sec } & $94^{\circ} \mathrm{C}$ & 35 cycles of : & $72^{\circ} \mathrm{C}$ & \\
\hline & $10 \mathrm{~min}$. & $\begin{array}{c}\text { Denaturation: } 94^{\circ} \mathrm{C} / 45 \mathrm{sec} \text {. } \\
\text { Annealing: } 50 / 45 \mathrm{sec} \text {. } \\
\text { Extension: } 72 / 45 \mathrm{sec} .\end{array}$ & $10 \mathrm{~min}$. & \\
\hline \multirow[t]{2}{*}{ sed } & $94^{\circ} \mathrm{C}$ & 35 cycles of : & $72^{\circ} \mathrm{C}$ & \\
\hline & $5 \mathrm{~min}$. & $\begin{array}{l}\text { Denaturation: } 94^{\circ} \mathrm{C} / 30 \mathrm{sec} \text {. } \\
\text { Annealing: } 48 / 30 \mathrm{sec} \text {. } \\
\text { Extension: } 72 / 30 \mathrm{sec} .\end{array}$ & $7 \mathrm{~min}$. & \\
\hline \multirow[t]{2}{*}{ mecA } & $94^{\circ} \mathrm{C}$ & 35 cycles of : & $72^{\circ} \mathrm{C}$ & \multirow{2}{*}{$\begin{array}{l}\text { McClure et al., } \\
2006\end{array}$} \\
\hline & $10 \mathrm{~min}$. & $\begin{array}{l}\text { Denaturation: } 94^{\circ} \mathrm{C} / 45 \mathrm{sec} \text {. } \\
\text { Annealing: } 50 / 45 \mathrm{sec} \text {. } \\
\text { Extension: } 72 / 45 \mathrm{sec} \text {. }\end{array}$ & $10 \mathrm{~min}$. & \\
\hline $\mathrm{coa}$ & $\begin{array}{l}94^{\circ} \mathrm{C} \\
10 \mathrm{~min} .\end{array}$ & $\begin{array}{l}35 \text { cycles of : } \\
\text { Denaturation: } 94^{\circ} \mathrm{C} / 1 \mathrm{~min} . \\
\text { Annealing: } 55 / 1 \mathrm{~min} . \\
\text { Extension: } 72 / 1 \mathrm{~min} .\end{array}$ & $\begin{array}{c}72^{\circ} \mathrm{C} \\
10 \mathrm{~min}\end{array}$ & $\begin{array}{c}\text { Iyer and } \\
\text { Kumosani, } 2011\end{array}$ \\
\hline \multirow[t]{2}{*}{ spa } & $94^{\circ} \mathrm{C}$ & 35 cycles of : & $72^{\circ} \mathrm{C}$ & \multirow{2}{*}{$\begin{array}{c}\text { Wada et al., } \\
2010\end{array}$} \\
\hline & 5 min. & $\begin{array}{l}\text { Denaturation: } 94^{\circ} \mathrm{C} / 30 \mathrm{sec} \text {. } \\
\text { Annealing: } 55 / 30 \mathrm{sec} \text {. } \\
\text { Extension: } 72 / 30 \mathrm{sec} \text {. }\end{array}$ & $7 \mathrm{~min}$. & \\
\hline \multirow[t]{2}{*}{ femA } & $94^{\circ}$ & 35 cycles of : & $72^{\circ} \mathrm{C}$ & \multirow{2}{*}{$\begin{array}{c}\text { Mehrotra et al., } \\
2000\end{array}$} \\
\hline & $5 \mathrm{~min}$. & $\begin{array}{l}\text { Denaturation: } 94^{\circ} \mathrm{C} / 30 \mathrm{sec} \text {. } \\
\text { Annealing: } 50 / 30 \mathrm{sec} \text {. } \\
\text { Extension: } 72 / 30 \mathrm{sec} \text {. }\end{array}$ & $7 \mathrm{~min}$. & \\
\hline
\end{tabular}

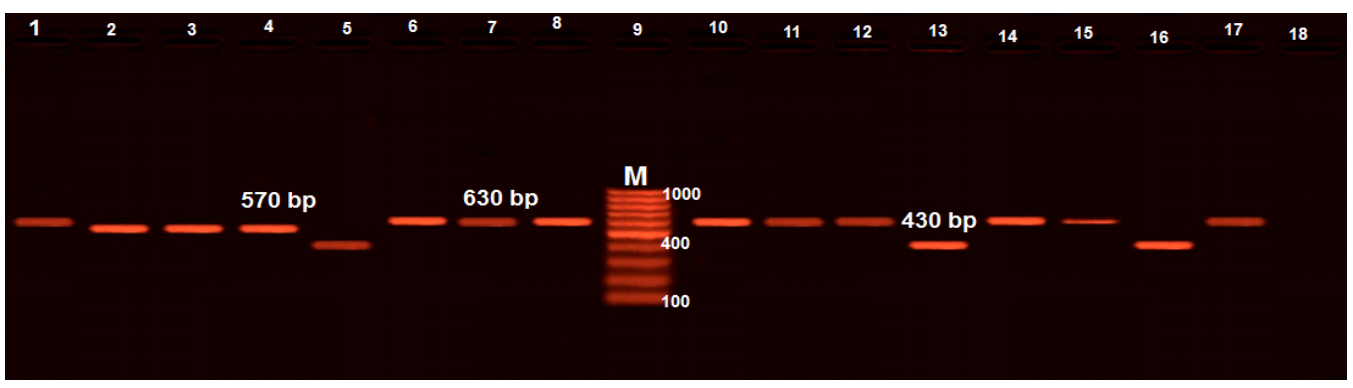

Fig. (1): Agarose gel electrophoresis of PCR products after amplification of coa gene with amplified product at $430 \mathrm{bp}, 570$ and 630bp. Lane (9) (M):100-600bp DNA Ladder "Marker" (100 Pharmacia). Lanes (5, 13 and16): positive carrying coagulase gene at $430 \mathrm{bp}$. Lanes (2, 3 and4): positive carrying coagulase gene at $570 \mathrm{bp}$. Lanes $(1,6,7,10,11,12,14,15$ and 17): positive carrying coagulase gene at $630 \mathrm{bp}$. Lane (8): Positive control (reference strain deposited to gene bank with accession no.Z33404). Lane (18): Negative control. 


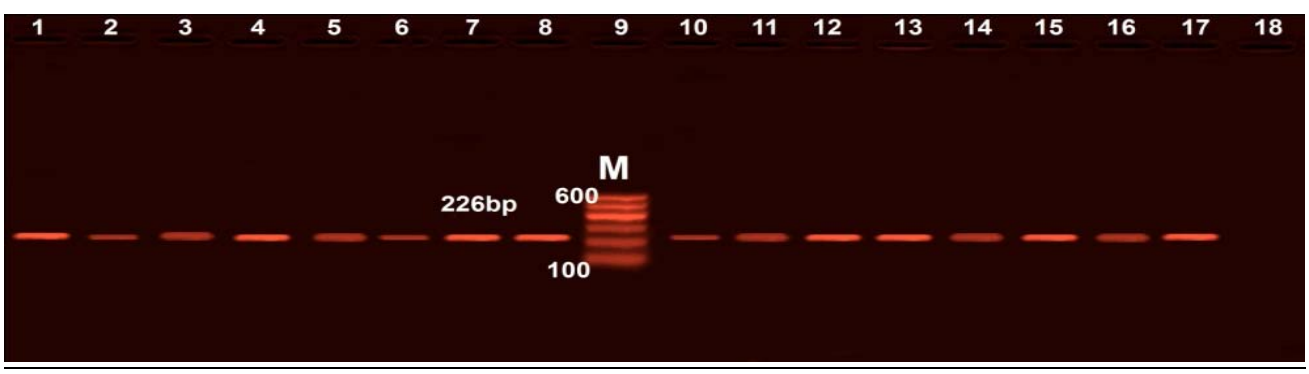

Fig. (2): Agarose gel electrophoresis of PCR products after amplification of spa (IgG-binding protein) gene at 226 bp amplified product. Lane 9 (M): 100-600bp DNA Ladder "Marker" (100 Pharmacia). All lanes (1: 17): positive isolates at 226 bp. Lane 8: Positive control (reference strain deposited to gene bank with accession no. P38507). Lane 18: Negative control.

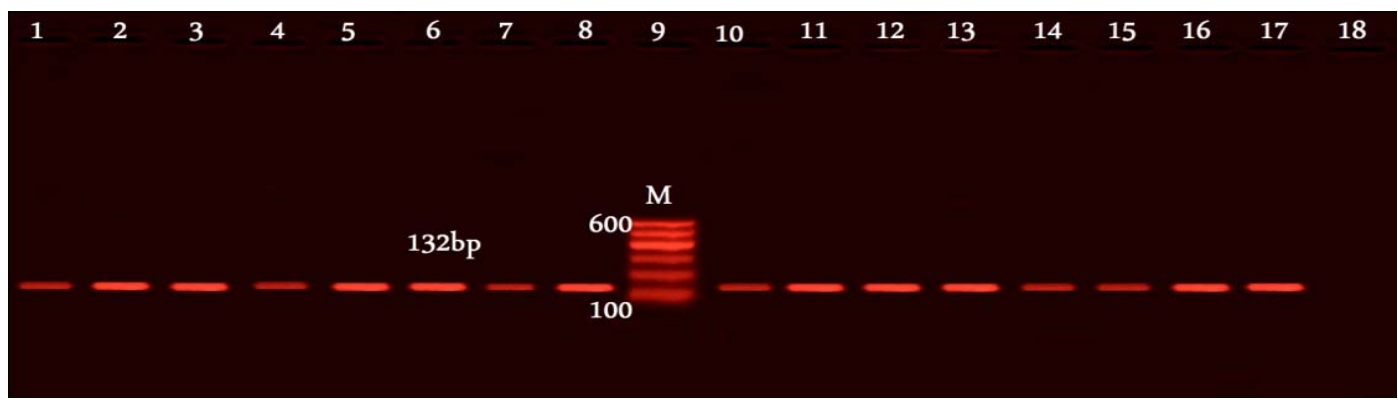

Fig. (3): Agarose gel electrophoresis of PCR products after amplification of femA gene at $132 \mathrm{bp}$ amplified product. Lane 9 (M): 100-600bp DNA Ladder "Marker" (100 Pharmacia). All lanes (1:17): positive isolates at $132 \mathrm{bp}$. Lane 8: Positive control (reference strain deposited to gene bank with accession no.NC_002952). Lane 18: Negative control.

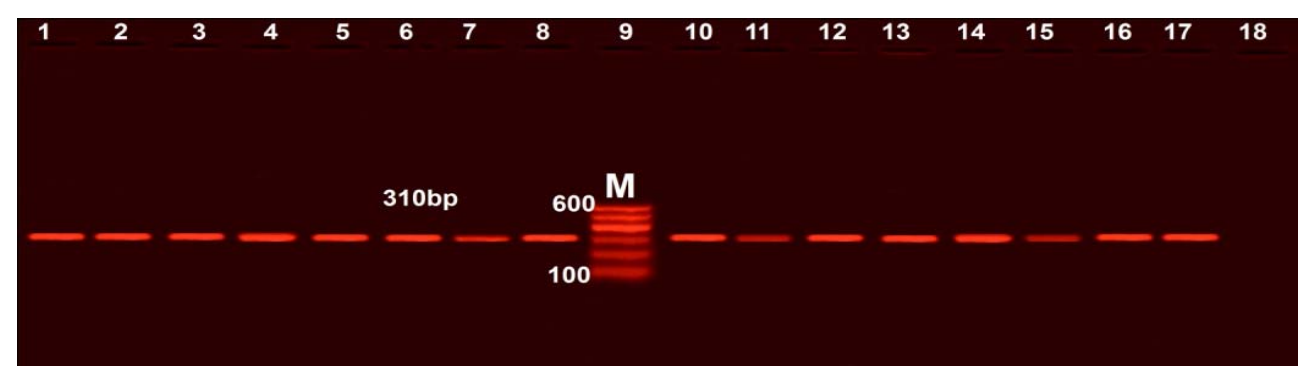

Fig. (4): Agarose gel electrophoresis of PCR products after amplification of mecA gene at 310bp amplified product. Lane 9 (M): 100-600bp DNA Ladder "Marker" (100 Pharmacia). All lanes (1:17): positive isolates at $310 \mathrm{bp}$. Lane 8: Positive control (reference strain deposited to gene bank with accession no.X52593). Lane 18: Negative control. 


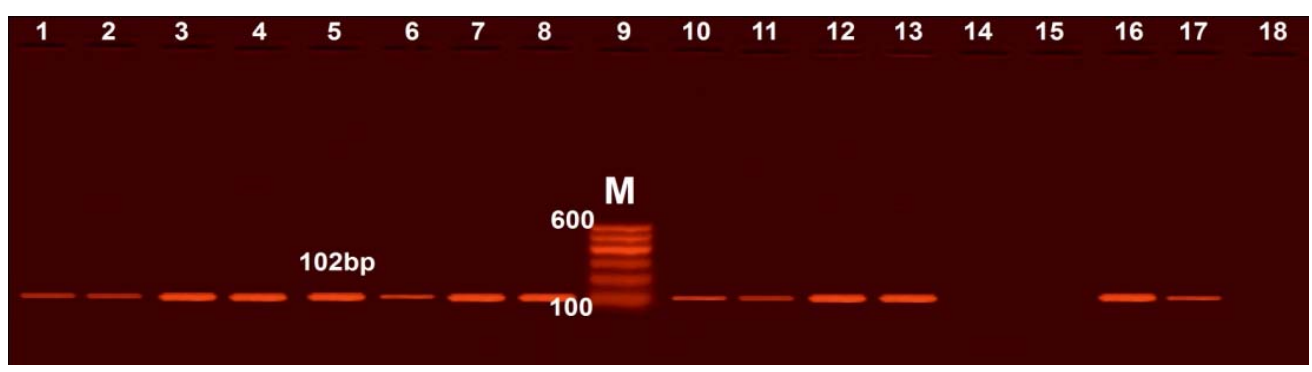

Fig. (5): Agarose gel electrophoresis of PCR products after amplification of sea gene at 102bp amplified product. Lane 9 (M): 100-600bp DNA Ladder "Marker" (100 Pharmacia). Lanes (1, 2, 3, 4, 5, 6, 7, 10, 11, 12, 13, 16 and 17): positive isolates at 102 bp. Lanes (14and 15): negative isolates. Lane 8: Positive control (reference strain deposited to gene bank with accession no. DQ641635). Lane 18: Negative control.

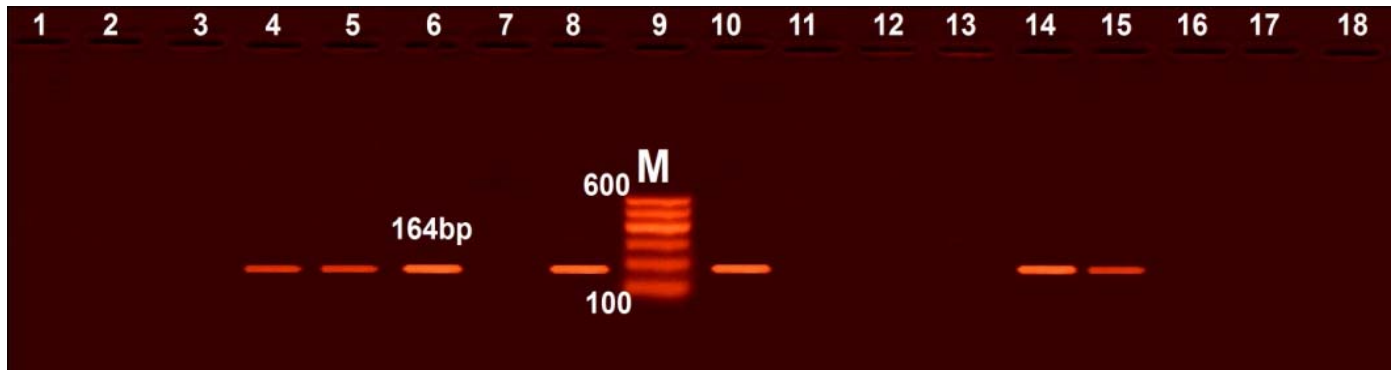

Fig. (6): Agarose gel electrophoresis of PCR products after amplification of seb gene at $164 \mathrm{bp}$ amplified product.Lane 9 (M): 100-600bp DNA Ladder "Marker" (100 Pharmacia). Lanes (4, 5, 6, 10, 14, 15): positive isolates at $164 \mathrm{bp}$. Lanes $(1,2,3,7,11,12,13,16,17)$ : negative isolates. Lane 8: Positive control (reference strain deposited to gene bank with accession no.AY518386). Lane 18: Negative control.

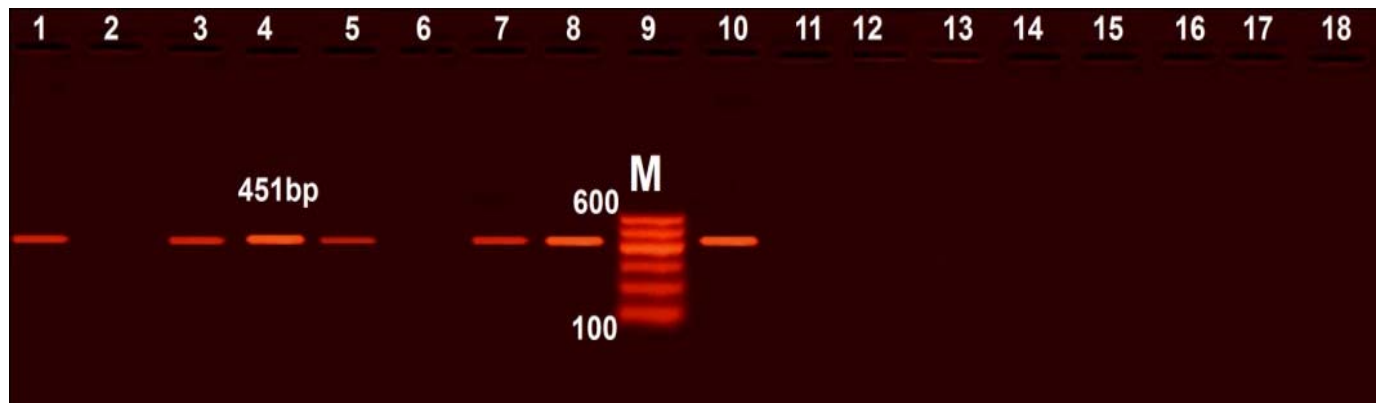

Fig. (7): Agarose gel electrophoresis of PCR products after amplification of sec gene at $451 \mathrm{bp}$ amplified product. Lane 9 (M): 100-600bp DNA Ladder "Marker (100 Pharmacia). Lanes (1, 3, 4, 5, 7 and 10): positive isolates at $451 \mathrm{bp}$. Lanes $(2,6,11,12,13,14,15,16$ and 17): negative isolates. Lane 8: Positive control (reference strain deposited to gene bank with accession no.AB084256). Lane 18: Negative control. 


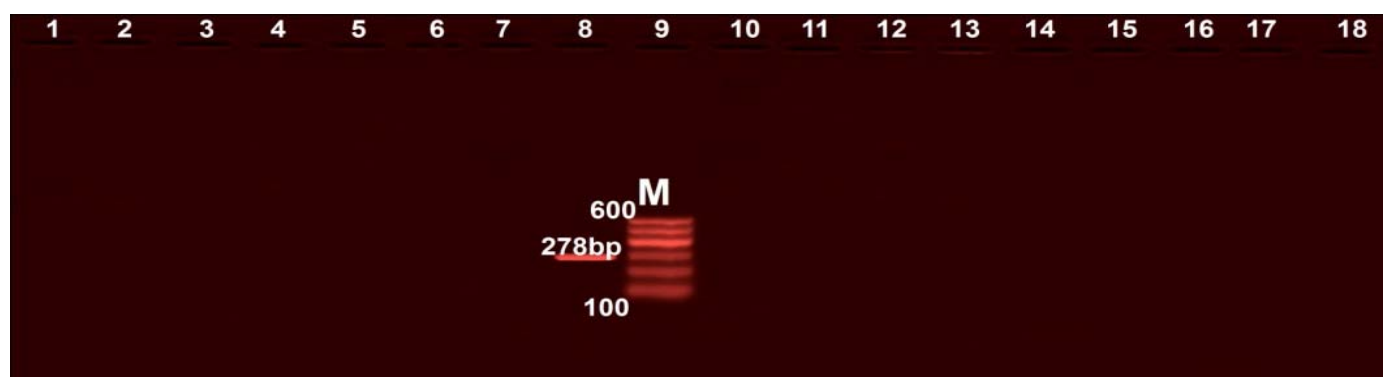

Fig. (8): Agarose gel electrophoresis of PCR products after amplification of sed gene at $278 \mathrm{bp}$ amplified product. Lane 9 (M): 100-600bp DNA Ladder "Marker (100 Pharmacia). All lanes (1:17): negative isolates. Lane 8: Positive control (reference strain deposited to gene bank with accession no.AY518388 at 278 bp).Lane 18: Negative control.

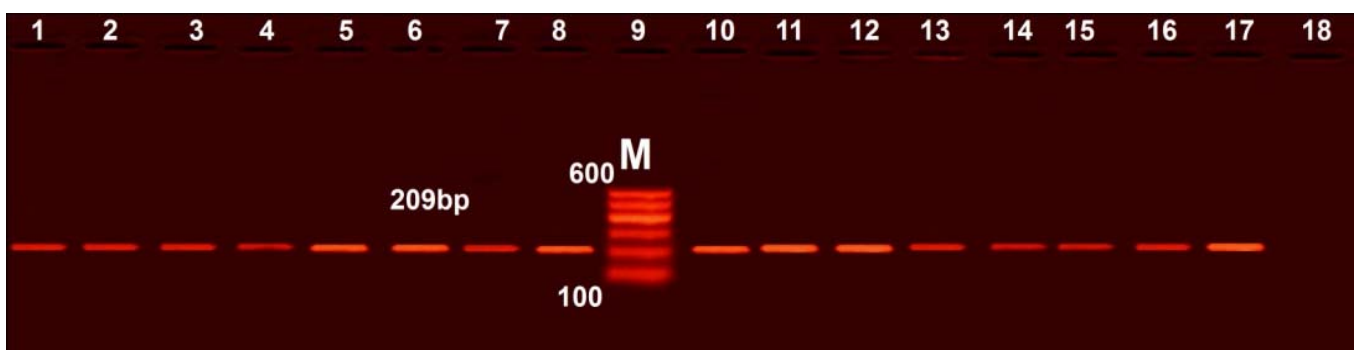

Fig. (9): Agarose gel electrophoresis of PCR products after amplification of see gene at $209 \mathrm{bp}$ amplified product. Lane 9 (M): 100-600 bp DNA ladder "Marker (100 Pharmacia). All Lanes (1:17 ): positive isolates at $209 \mathrm{bp}$. Lane 8: positive control (reference strain deposited to gene bank with accession no.AY518387). Lane 18: Negative control.

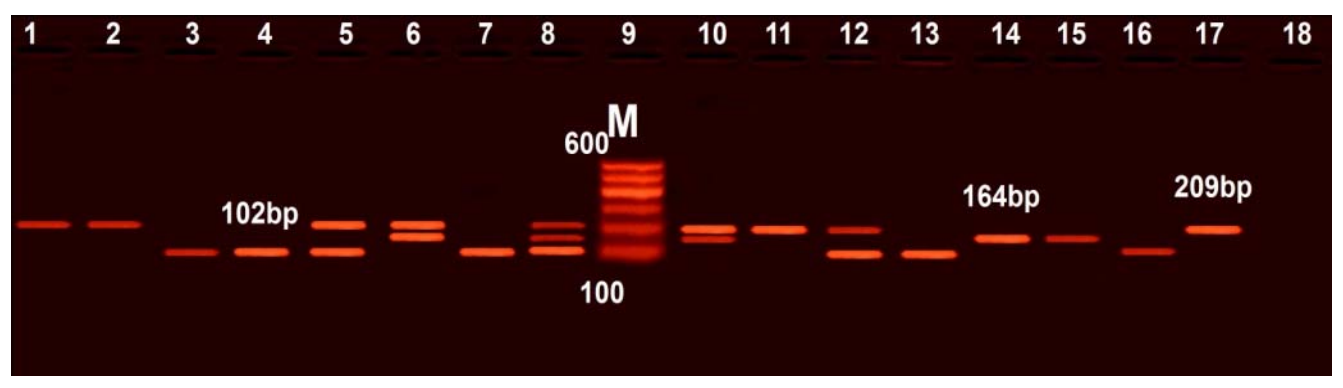

Fig. (10): Agarose gel electrophoresis of PCR products after amplification of sea, seb and see virulence genes in a multiplex PCR. Lane 9 (M):100-600 bp DNA Ladder "Marker" (100 Pharmacia). Lanes (1, 2,11and17): S. aureus had one virulence gene see only at $209 \mathrm{bp}$. Lanes $(3,4,7,13$ and 16): S. aureus had one virulence genes sea only at $102 \mathrm{bp}$. Lanes (14 and 15): S. aureus had one virulence genes seb at 164 bp. Lanes (5 and12): S. aureus had both sea and see virulence genes. Lanes (6 and10): S. aureus had both seb and see virulence genes. Lane 8: Positive control (reference strain). Lane 18: Negative control.

\section{DISCUSSION}

S. aureus is recognized worldwide as a frequent cause of subclinical intramammary infections in dairy cows (Straub et al., 1999). The identification of 15 S. aureus isolates in the present study could be performed by conventional methods and by PCR technology using nucleotide primers targeting different gene. Various virulence genes encoding coagulase gene, the $\operatorname{IgG}$ binding region of protein $\mathrm{A}$ and enterotoxins (sea-see). Comparable PCR base detection studies have been described 
by other investigators (Algammal et al., 2013).

The amplification of the coa gene displayed three different size polymorphisms with approximately $430 \mathrm{bp}$ for 3 isolates $(20 \%)$, $570 \mathrm{bp}$ for 3 isolates $(20 \%)$ and $630 \mathrm{bp}$ for 9 isolates $(60 \%)$. This attributed to the presence of more than one allelic form of the coagulase gene as mentioned by Aslantas et al., (2007). These results are in exact with the findings of Gharib et al., (2013) who suggested that an amplicon of about $600 \mathrm{bp}$ are predominant in bovine strains. On the other hand, Schledgelova et al., (2003) reported the size of coa gene PCR product of $S$. aureus isolates from dairy cow gave 4 classes at $650,730,810$ and $1050 \mathrm{bp}$. Class $730 \mathrm{bp}$ was the most common class between the isolates.

The other virulence factor with great concern is staphylococcal enterotoxins as they are very resistant to heat and gastrointestinal protease that justifies why they remains active after thermal processing and the genes responsible for encoding these enterotoxins were detected by uniplex and multiplex PCR. Production of sea, seb, sec, sed, and see by $S$. aureus strains associated with bovine mastitis has been described by Rall et al., 2008 .

Uniplex and multiplex PCR results obtained in this study showed that $100 \%$ of $S$. aureus isolates were positive for one or more enterotoxin. The occurrence of multiple toxin genes in S. aureus was considered rare (Jorgensen et al., 2005). This supports the suggestion that SE and SE-like toxins may cause bovine mastitis by depressing the bovine immune system (Ferens et al., 1998).

Among these classical SE genes see and sea showed the highest prevalence rate in the present study. This is a cause of concern as a potential health risk for humans, because most $S$. aureus strains that possess the see and sea gene produce toxins, which is a major etiological factor of staphylococcal food poisoning (Hwang et al., 2010).

The predominant classical SE varied from country to country: In Tehran\& Mashhad see gene (Sahebekhtiari et al., 2011); In Canada, see and sea gene (Mehrotra et al., 2000); In Brazil, sea gene (Rall et al., 2014); In Hungary, seb gene (Zouharova and Rysanek, 2008); In Iraq and Argentina, sec gene (Khudor et al., 2012) and (Nederet al., 2011), respectively; In Italy, sed gene (Carfora et al., 2015) and here in Egypt see was found in $100 \%(15 / 15)$ by uniplex PCR. Additionally, it was also found in combination with sea and seb genes by multiplex PCR. The prevalence of see gene and combination with other enterotoxins has reported elsewhere (Mehrotra et al., 2000) and (El-Seedy et al., 2010). Irionically, in this study sed gene is not detected neither by uniplex nor multiplex PCR. It was matched with Abd EL-Tawab, et al., (2015).

It is worth mentioning that, Protein $\mathrm{A}$ is a component of $S$. aureus cell wall and is covalently bound to the peptidoglycan. The PCR amplification of the gene encoding the IgG-binding region of protein A revealed band of $226 \mathrm{bp}$ for all S. aureus strains $(100 \%)$, These results agreed with those obtained by Enany et al., 2013. While other authors detected the immunoglobulin $G$ binding region of protein $\mathrm{A}$ with different percentage as (Mehndiratta, et al., 2009) (94.6\%) and (Bekhit et al., 2010) (32.4\%). In addition to virulence, a major concern in the control of mastitis is resistance of the etiological agent to antibiotics. Staphylococcal resistance to methicillin is increased nowadays and associated with acquisition of the staphylococcal cassette chromosome mecA and femA which is a protein encode the level expression of methicillin resistance (kumaret al., 2010). Therefore, the detection of femA and together with mecA by PCR was considered to be a more reliable indicator to identify MRSA (Vannuffel et al., 2000).

The femA gene product, a $48-\mathrm{kDa}$ protein (cytoplasmic protein), has been suggested to have a role in cell wall metabolism and is reported to be present in all $S$. aureus species during the active growth phase. This gene was a necessary for the expression of 
methicillin resistance in Staphylococcus aureus and also involved in the biosynthesis of staphylococcal cell walls (Johnson et al., $1995)$ and is universally presented in all $S$. aureus isolates (100\%) similar as Mehrotra et al., (2000).

In the current study genotypically mecA gene was detected with high percent $(100 \%)$ in all S. aureus isolates with a $310 \mathrm{bp}$ amplified product matched with Omar et al., (2014) in Egypt; Mehrotra et al., (2000) in Canada and Saidi et al., (2015) in Algeria. This high rate of methicillin resistance can be attributed to the random use of methicillin in farms of delta region and the incidence of mecA gene represent a great hazard to public health as it may be transfer to human.

\section{CONCLUSION}

Data presented in this study showed abroad distribution of identical related $S$. aureus clones are responsible for the mastitis situations in Egypt with highly prevalence rate of methicillin resistance among the obtained isolates which represent an alarm for a great hazard to public health.

\section{REFERENCES}

Abd EL-Tawab, A.A., Abou El-Roos, N.A., El-Gendy, A.A.M. 2015. Bacteriological and molecular studies on staphylococcus aureus isolated from raw milk. Benha veterinary medical journal, 28 (1):88-97.

Algammal, A.M., Enany, M.E., Khafagy, A.A. 2013. PCR based detection of genes encoding virulence determinants in Staphylococcus aureus strains isolated from bovine milk. Arabian journal of science.Home $>$ Volume 2: First Young Researchers Conference at SCU (YRC2013).

Aslantas, O., Demir, C., Turutoglu, H., Cantekin, Z. Ergun, Y., Dogruer, G. 2007. Coagulase gene polymorphism of Staphylococcus aureus isolated from subclinical bovine mastitis. Turk. J. Vet. Anim. Sci., 31(4):253-257.

Bekhit, M.M.S., Muharram, M.M., Alhousiny, I.M., Hashem, M.E.S.Y. 2010. Molecular detection of genes encoding virulence determinants in Staphylococcus aureus strains isolated from bovine mastitis. $\mathrm{J}$. Appl. Sci. Res., 6(2): 121-128.

Carfora, V., Caprioli,A., Marri, N., Sagrafoli, D., Boselli, C., Giacinti, G.,Giangolini, G., Sorbara,L., Dottarelli, S., Battisti,A., Amatiste, S. 2015. Enterotoxin genes, enterotoxin production and methicillin resistance in Staphylococcus aureus isolated from milk and dairy products in Central Italy. International Dairy Journal, 42: 12-15.

Chiang, Y. C., Chang, L. T., Lin, C. W., Yang, C. Y., Tsen, H.Y. 2006. PCR Primers for the detection of SE K, L and $\mathrm{M}$ and survey of Staphylococcal enterotoxin types in $S$. aureus isolates from food poisoning cases in Taiwan. J. Food Prot., 69(5):10721079.

El-Seedy, F.R., El-Shabrawy, M., Hakim, A. S., Dorgham, S.M., Nagwa, A.S., Bakry, M.A., Osman, N.M.N. 2010. Recent techniques used for isolation and characterization of Staphylococcus aureus from mastitic cows. Journal of American Science, 6(12):701-708.

Enany, M.E., Younes, S., A L gammal, A.M., Salem, M., El Dieb, H.A. 2013. Phenotypic and genotypic characterization of Staphylococcus aureus isolated from clinical and subclinical bovine mastitis. SCVMJ, XVIII, (1) 139-147.

Ferens, W.A., Goff, W.L., Davis, W.C., Fox, L.K., Deobald, C., Hamilton, M.J., Bohach, G.A. 1998. Induction of type 2 cytokines by a staphylococcal enterotoxin 
superantigen. J. Nat. Toxins, 7, 193213.

Fitzgerald, J.R., Hartigan, P.J., Meaney, W.J., Smyth, C.J. 2000. Molecular population and virulence factor analysis of Staphylococcus aureus from bovine intramammary infection. J. Appl. Microbiol., 88:1028-1037.

Foster, T. 2005. Immune evasion by staphylococci. Nat. Rev. Microbiol., 3(12):948-958.

Gentilini E., Denamiel G., Betancor A. 2000. Antimicrobial suscettibility of coagulase negative stphylococci isolated from bovine mastitis in Argentina. J. Dairy Sci., 85:19131917.

Gharib, A.A., Attia, M.A.A., Bendary, M.M. 2013. Detection of the coa gene in Staphylococcus aureus from different sources by polymerase chain reaction. BendaryIntl. J. Microbiol. Res., 4 (1): 37-42.

Goñi, P., Vergara, Y., Ruiz, J., Albizu, I., Vila, J., Gómez-Lus, R. 2004. Antibiotic resistance and epidemiological typing of Staphylococcus aureus strains from ovine and rabbit mastitis. Int. J. Antimicrob. Agents, 23(3):268-72.

Hwang, S.Y., Park, Y.K., Koo, H.C., Park, Y.H. 2010. Spa typing and enterotoxin gene profile of Staphylococcus aureus isolated from bovine raw milk in KoreaJ. Vet. Sci., 11(2), 125-131.

Iyer, A.P., Kumosani, T.A. 2011. PCR based detection of nosocomial infection causing MRSA (Methicillin resistant Staphylococcus aureus). 2nd International Conference on Biotechnology and Food Science IPCBEE vol.7 (2011) (C) (2011) IACSIT Press, Singapore.

Johnson, S., Dominique, K., Labischinski, H. 1995. FemA of Staphylococcus aureus: Isolation and immunodetection, FEMS Microbiol. Lett., 132:221-228.
Jorgensen, H.J., Mork, T., Hogasen, H.R. Rorvik, L.M. 2005. Enterotoxigenic Staphylococcus aureus in bulk milk in Norway. J. Appl. Microbiol., 99: 158166.

Khudor, M.H., Abbas, B.A., Idbeis, H.I. 2012. Detection of enterotoxin genes of Staphylococcus aureus isolates from raw milk. Bas. J. Vet. Res., 11(1): 254-264.

Kirkan, S., Goksoy, E.O., Kaya, O. 2005. Identification and antimicrobial susceptibility of Staphylococcus aureus and coagulase negative Staphylococci from bovine mastitis in the Aydin Region of Turkey. Turk J. Vet. Anim. Sci., 29:791-796.

Kobayashjf, N., Wu, H.; Kojima, K., Taniguchp, K., Urasawa, S., Uehara, N., Omizu, Y., Kish, Y., Yagihash, A., Kurokawa, I. 1994. Detection of $m e c \mathrm{~A}, f e m \mathrm{~A}$, and $f e m \mathrm{~B}$ genes in clinical strains of Staphylococci using polymerase chain reaction.Epidemiol.Infect., 113 (2), 259-266.

Koneman, E.W., Allen, S.D., Janda, W.M., Schreckenberger, M.P.C., Winn Jr. W.C. 2001.

DiagnósticoMicrobiológico - Texto e Atlas Colorido, $5^{\text {a }}$ ed. MEDSI, São Paulo.

Kot, B., Piechota, M., Wolska, K.M., Frankowska, A., Zdunek, E., Binek, T., Kłopotowska, E.Antosiewicz, M. 2012. Phenotypic and genotypic antimicrobial resistance of staphylococci from bovine milk. Pol. J. Vet. Sci., 15: 677-683.

Kumar, R., Surendran, P.K., Thampuran, N. 2010. Evaluation of culture media for selective enrichment and isolation of Salmonella in seafood. J. AOAC Int.; 93(5): 1468-1471.

McClure, J.A, Conly, J.M., Lau, V., Elsayed, S., Louie, T, Hutchins, W, Zhang, K. 2006. Novel multiplex PCR assay for detection of the staphylococcal virulence marker Panton-Valentine leukocidin genes 
and simultaneous discrimination of methicillin susceptible from resistant staphylococci. J. Clin. Microbiol., 44: 1141-114.

Mehndiratta, P., Bhalla, P., Ahmed, A., Sharma, Y. 2009. Molecular typing of methicillin resistant Staphylococcus aureus strains by PCR-RFLP of SPA gene: a reference laboratory perspective, Indian Journal of Medical Microbiology, 27(2):116-122.

Mehrotra, M., Wang, G., Johnson, W.M. 2000. Multiplex PCR for detection of genes for Staphylococcus aureus enterotoxins, exfoliative toxins, toxic shock syndrome toxin 1, and methicillin resistance. Journal of clinical microbiology, 38(3): 1032-5.

Momtaz, H., Rahimi, E., Tajbakhsh, E. 2010. Detection of some virulence factors in Staphylococcus aureus isolated from clinical and subclinical bovine mastitis in Iran. African J. of Biotechnology, 9 (25): 3753-3758.

Neder, V.E., Canavesio, V.R., Calvinho, L.F. 2011.Presence of enterotoxigenic Staphylococcus aureus in bulk tank milk from Argentine dairy farms.Revista Argentina de Microbiología, 43: 104106.

Normanno, G., Firinu, A., Virgilio, S., Mula, G., Dambrosio, A., Poggiu, A., Decastelli, L., Mioni, R., Scouta, S., Bolzoni, G., Di Giannatale, E., Salinetti, A.P., La Salandra, G., Bartoli, M., Zuccon, F., Pirino, T., Sias, S., Parisi, A., Quaglia, N.C., Celano, G.V. 2005. Coagulase positive staphylococci and Staphylococcus aureus in food products marketed in Italy. Int. J. Food Microbiol., 98: 73-79.

Omar, N.Y., Ali, H.A.S., Harfoush, R.A.H., El Khayat, E.H. 2014. Molecular Typing of methicillin resistant Staphylococcus aureus clinical isolates on the basis of protein A and coagulase gene polymorphisms. International Journal of Microbiology
Volume 2014, Article ID 650328, 11 pages.

Palma, M., Haggar A., Flock J. 1999. Adherence of Staphylococcus aureus is enhanced by an endogenous secreted protein with broad binding activity. J. Bacteriol., 181(9):28402845.

Radostits, O.M., Blood, D. C., Gay, C.C. 1994. Veterinary Medicine $8^{\text {th }}$ ed. ELBS Bailliere Tindall. London.

Rall, V.L., Miranda, E.S., Castilho, I.G., Camargo, C.H., Langoni, H., Guimarães, F.F., Araújo Júnior, J.P., Fernandes Júnior, A. 2014. Diversity of Staphylococcus species and prevalence of enterotoxin genes isolated from milk of healthy cows and cows with subclinical mastitis. J. Dairy Sci., 97(2):829-37.

Rall, V.L.M., Viera, F.P., Rall, R., Vites, R.L., Fernandes, A. J., Candeis, J.M.G., Cardoso, K.F.G., Araujo, J.P. J. 2008. PCR detection of S. aureus strains isolated from raw and pasteurized milk. Vet. Microbial., 132(3-4): 408-413.

Reinoso, E.B. 2004. Análisis epidemiológicoy molecular de cepas de Staphylococcus aureus de distintosorígenes. Tese de Doutorado, Instituto de Microbiologia, Universidad Nacional de Rio Cuarto, Argentina. 199p.

Sahebekhtiari, N., Nochi, Z., Eslampour, M.A., Dabiri, H., Bolfion, M., Taherikalani, M., Khoramian, B., Zali, M.R., Emaneini, M. 2011. Characterization of $S$. aureus strains isolated from raw milk of bovine subclinical mastitis in Tehran and Mashhad. Acta Microbial. Immunol. Hung., 58 (2):113-121.

Saidi, R., Cantekin, Z., Khelef, D., Ergün, Y., Solmaz, H., Kaid, R. 2015. Antibiotic susceptibility and molecular identification of antibiotic resistance genes of staphylococci isolated from bovine mastitis in 
Algeria. Kafkas Univ. Vet. Fak. Derg. J., 21 (4): 513-520.

Schlegelova, J., Dendis, M., Benedik, J., Babak, V., Rysanek, D. 2003. Staphylococcus aureus isolates from dairy cow and human on a farm differ in coagulase genotype. J. Vet. Micr., 92: 327-334.

Seyffert, N., Le Marechel, C., Jardin, J., McCulloch, J.A., Rosado, F.R., Miyoshi, A., Even, S., Jan, G., Berkova, N., Vauter, E., Thiery, R., Azevedo, V., Le Loir, Y. 2012. Staphylococcus aureus proteins differentially recognized by the ovine immune response in mastitis or nasal carriage. Vet. Microbial., 157(34):439-47.

Straub, J.A., Hertel, C., Hammes, W.E. 1999. A $23 \mathrm{~S}$ rRNA-targeted polymerase chain reaction based system for detection of Staphylococcus aureus in meat starter cultures and dairy products. J. Food. prot., 62: 1150-1156.
Thomas, D., Chou, S., Dauwalder O., Lina, G. 2007. Diversity in S. aureus enterotoxins. Chem. Immunol. Allergy, 93:24-41.

Vannuffel, P., Gigi, J., Ezzedine, H., Vandercam, B., Delmee, M., Wauters, G., Gala, J.L.2000. Specific detection of methicillin resistant Staphylococcus species by multiplex PCR, Journal of Clini. Microbiol., 38(1):2864-2867.

Wada, M., Lkhagvador, J.E., Bian,L., Wang, C., Chiba, Y., Nagata, S., Shimizu, T.,Yamashiro,Y., Asahara, T., Nomot, K. 2010. Quantitative reverse transcription PCR assay for the rapid detection of methicillin resistant Staphylococcus aureus. J. Applied Microbiology, 108(3): 779-788.

Zouharova, M., Rysanek, D. 2008. Multiplex PCR and RPLA identification of Staphylococcus aureus enterotoxigenic strains from bulk tank milk. Zoo. Pub. HIth., 55(6): 313-319. 